\title{
Synthetic cathelicidin LL-37 reduces Mycobacterium avium subsp. paratuberculosis internalization and pro-inflammatory cytokines in macrophages
}

\author{
Karina M. Cirone ${ }^{1} \cdot$ Priyoshi Lahiri ${ }^{2} \cdot$ Ravi Holani $^{2} \cdot{\text { Yi Lin } \operatorname{Tan}^{2}}^{2}$ Rakel Arrazuria ${ }^{2} \cdot$ Jeroen De Buck ${ }^{2}$.

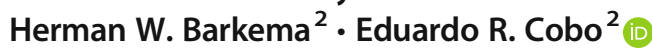

Received: 27 November 2018 / Accepted: 20 August 2019/Published online: 2 September 2019

(C) Springer-Verlag GmbH Germany, part of Springer Nature 2019

\begin{abstract}
Mycobacterium avium subsp. paratuberculosis (MAP) causes chronic diarrheic intestinal infections in domestic and wild ruminants (paratuberculosis or Johne's disease) for which there is no effective treatment. Critical in the pathogenesis of MAP infection is the invasion and survival into macrophages, immune cells with ability to carry on phagocytosis of microbes. In a search for effective therapeutics, our objective was to determine whether human cathelicidin LL-37, a small peptide secreted by leuckocytes and epithelial cells, enhances the macrophage ability to clear MAP infection. In murine (J774A.1) macrophages, MAP was quickly internalized, as determined by confocal microscopy using green fluorescence protein expressing MAPs. Macrophages infected with MAP had increased transcriptional gene expression of pro-inflammatory TNF- $\alpha$, IFN- $\gamma$, and IL$1 \beta$ cytokines and the leukocyte chemoattractant IL-8. Pretreatment of macrophages with synthetic LL-37 reduced MAP load and diminished the transcriptional expression of TNF- $\alpha$ and IFN- $\gamma$ whereas increased IL-8. Synthetic LL-37 also reduced the gene expression of Toll-like receptor (TLR)-2, key for mycobacterial invasion into macrophages. We concluded that cathelicidin LL37 enhances MAP clearance into macrophages and suppressed production of tissue-damaging inflammatory cytokines. This cathelicidin peptide could represent a foundational molecule to develop therapeutics for controlling MAP infection.
\end{abstract}

Keywords Mycobacterium avium subsp. paratuberculosis $\cdot$ Macrophages $\cdot$ Cathelicidin $\cdot$ LL-37 $\cdot$ IL-8

\section{Introduction}

Mycobacterium avium subsp. paratuberculosis (MAP) is the causative agent of paratuberculosis or Johne's disease in domestic and wild animals. In cattle, MAP causes chronic enteritis, clinically characterized by diarrhea, weight loss, and progressive emaciation that leads to reduced production and premature culling or death (Mortier et al. 2015). Transmission of MAP is generally initiated with the oral ingestion of MAP

Electronic supplementary material The online version of this article (https://doi.org/10.1007/s00441-019-03098-4) contains supplementary material, which is available to authorized users.

Eduardo R. Cobo

ecobo@ucalgary.ca

1 Department of Animal Production, National Agricultural Technology Institute, Buenos Aires, Argentina

2 Department of Production Animal Health, Faculty of Veterinary Medicine, University of Calgary, Calgary, AB, Canada bacilli excreted in feces or milk (Derakhshani et al. 2016; Corbett et al. 2018). This infection with MAP often occurs during the first months of life and elicits a slowly progressive inflammatory response in the gastrointestinal tract, not clinically apparent for months or years. Moreover, only a minority of cattle (10-15\%) exposed to MAP eventually develop clinical disease (Mortier et al. 2015).

Early stages of MAP infection are defined by the period between oral uptake of MAP and the establishment of a persistent infection within macrophages. Macrophages are primary target cells for MAP persistance and replication (Koets et al. 2015), but they may elicit bactericidal effects in controlling the bacterium. In this host-pathogen interaction, mycobacteria interact with several Toll-like receptors (TLRs) on macrophages, including TLR-2 and TLR-4 (Quesniaux et al. 2004). Signaling of MAP through TLR-2 suppress antimicrobial responses and antigen presentation in macrophages (Weiss et al. 2008). The location of MAP into phagosomes within macrophages aids in the bacterial survival by blocking phagosome acidification and limiting fusion between 
phagosomes and lysosomes (Sturgill-Koszycki et al. 1994). However, when activated (e.g., by stimulation with interferon gamma (IFN- $\gamma)$ ), macrophages can eliminate intracellular mycobacteria through increased synthesis of proinflammatory cytokines (IL-1, IL-6, TNF- $\alpha$ ) (Sohal et al. 2008) and lysosomal degradation (Alonso et al. 2007).

Murine models have been key to study MAP pathogenesis. Whereas mice are not natural host of MAP and some mice strains (e.g., C3H) are resistant to MAP infection (Chiodini and Buergelt 1993; Tanaka et al. 1994), experimental challenge with MAP via intraperitoneal (Huntley et al. 2005; Shin et al. 2006), endovenous (Rosseels et al. 2006), and oral (Cooney et al. 2014) routes reproduced histological and immunological features similar to those observed in ruminants (Hines et al. 2007). Moreover, murine macrophages (including phagocytic J774.A1 cells) have been used to decipher host mycobacteria interactions and intracellular growth characteristics of MAP (Kuehnel et al. 2001; Hostetter et al. 2003; Sonawane et al. 2011; Santos et al. 2014). In search for therapeutics that can "instruct" macrophages to control MAP, cathelicidins, small cationic peptides produced by neutrophils, macrophages, and epithelial cells with broad-spectrum antimicrobial activity against bacteria, fungi, and enveloped viruses, are of interest (Zanetti 2005; Holani et al. 2018). Cathelicidins are present in many mammalian species, with several cathelicidins reported in cattle (Young-Speirs et al. 2018). Humans and mice are unique species to study these peptides, as there is only one type of cathelicidins in humans (cathelicidin antimicrobial peptide CAP-18 or leucineleucine with 37 amino acids residue (LL-37)) and in mice (cathelicidin-related antimicrobial peptide (CRAMP)) (Zanetti 2005). LL-37 is a unique target molecule drug model for mycobacteria related diseases, as it has antimicrobial activity against $M$. smegmatis, M. bovis BCG, and M. tuberculosis (H37Rv), in both human monocyte-derived macrophages and murine macrophages (Sonawane et al. 2011). However, the role of cathelicidins in MAP, as antimicrobial or immunomodulator, is largely unknown. Thus, we aimed to characterize the fate of MAP in macrophages treated with synthetic LL-37, as a cathelicidin model, to assess its therapeutic potential in controlling MAP infection.

\section{Materials and methods}

\section{Macrophage}

Roles of cathelicidins in modulating macrophage functions in controlling MAP were studied in murine monocyte/ macrophage cells (J774A.1; ATCC® TIB-67 ${ }^{\mathrm{TM}}$ ). This adherent monocyte cell line has phagocyte characteristics (Ralph et al. 1975; Hostetter et al. 2003), and it is susceptible to intracellular pathogenic mycobacteria (Hasan et al. 1997;
Via et al. 1998). Cells were maintained in Dulbecco's modified Eagle's medium (11995123, Gibco, Thermo Fisher) with $10 \%$ fetal bovine serum (FBS) (A3160702; Gicbo, Thermo Fisher), $1 \%$ sodium pyruvate $(1 \mathrm{mM}$; 11360070 ; Thermo Fisher), $1.9 \%$ sodium bicarbonate $(1 \mathrm{mM} ; 25080094$; Thermo Fisher), L-glutamine and penicillin $(100 \mathrm{U} / \mathrm{mL})$, and streptomycin $(100 \mu \mathrm{g} / \mathrm{mL} ; 15140122$, Thermo Fisher). Cells were grown in a humidified environment of $95 \%$ air and $5 \%$ $\mathrm{CO}_{2}$ at $37^{\circ} \mathrm{C}$.

\section{Mycobacterium avium subsp. paratuberculosis}

MAP strains A1 157 (isolated from a dairy cow with clinical Johne's disease in Alberta, Canada) (Ahlstrom et al. 2015, 2016a, b) and K-10 (ATCC BAA-969, isolated from a dairy cow with Johne's disease in Wisconsin), genetically similar, with low diversity and clustered together in the main clade (Ahlstrom et al. 2015, 2016a, b) were utilized. Both MAP strains were cultured in Middlebrook (MB) 7H9 medium containing $0.2 \%$ glycerol, $10 \%$ oleic acid-dextrose-catalase (OADC), and mycobactin $\mathrm{J}(2.0 \mathrm{mg} / \mathrm{L})$ (Allied Monitor) at $37^{\circ} \mathrm{C}$, in a shaking incubator at $120 \mathrm{rpm}$. To visualize the mycobacteria inside macrophages, MAPs expressing green fluorescent protein (GFP) were obtained by the transformation of the wild-type strains with a recombinant (pWES-4) plasmid expressing the GFP (Parker and Bermudez 1997). GFP MAPs were selectively cultured adding kanamycin $(100 \mu \mathrm{g} / \mathrm{mL})$. Both MAP K10 GFP (Parker and Bermudez 1997) and MAP A1 157 GFP were comparatively evaluated through macrophage invasion to confirm the MAP virulence after transformation. Cultured MAP concentration (bacteria/mL) was calculated by turbidity absorbance at $600 \mathrm{~nm}\left(\mathrm{OD}_{600}\right.$ 0.5 equivalent to $1 \times 10^{8}$ cells $/ \mathrm{mL}$ ) (Lamont et al. 2012).

\section{Co-culture of macrophages and MAP}

Macrophages were seeded at $1 \times 10^{5}$ cells/well (12-well plates; Greiner Bio-One) for transcriptional gene expression and ELISAs and at $1 \times 10^{4}$ cells/chamber (8-well chambers) for confocal immunofluorescence microscopy. Wells were examined by phase-contrast microscopy to confirm macrophage adherence. MAP culture (wild-type or GFP-expressing strains) was pelleted $(1350 \mathrm{~g}, 10 \mathrm{~min})$ and washed several times in sterile phosphate-buffered saline (PBS). The pellet was dissolved in Dulbecco's modified Eagle's medium, vortexed (5 $\mathrm{min}$ ) and repeatedly drawn through a sterile 20 gauge needle.

Macrophage were pretreated with synthetic recombinant LL-37 (H6224, Bachem) $(2-10 \mu \mathrm{M} ; 1$ h) or inert control, washed several times in sterile PBS and challenged with MAP multiplicities of infections (MOIs) 1 and 5. MOIs were confirmed by MAP quantitative PCR (qPCR) as $1.6 \times 10^{5}$ and $4.3 \times 10^{5}$ for MOI 1 and 5, respectively. Cells were incubated 
for up to $24 \mathrm{~h}$ at $37^{\circ} \mathrm{C}$ in a humidified environment $\left(95 \% \mathrm{O}_{2}\right.$ and $5 \% \mathrm{CO}_{2}$ ), washed with PBS and further processed for RNA extraction or imaging. To obtain factors secreted from macrophages infected with MAP, supernatants were collected, centrifuged $\left(1350 \mathrm{~g} ; 15 \mathrm{~min}, 4^{\circ} \mathrm{C}\right)$ and pellets discharged.

\section{Intracellular identification of MAP in macrophages}

Macrophages infected with GFP-MAP were rinsed with PBS and $200 \mu \mathrm{L}$ of diluted trypan blue $0.2 \%(w / v)$ were added $(10$ $15 \mathrm{~s})$ to quench fluorescence of non-internalized bacteria. Macrophages were fixed in formaldehyde solution $3.7 \%(v /$ v) (10 min, room temperature (RT)), rinsed in cold PBS, blocked with PBS and 1\% $(w / v)$ bovine serum albumin (20 min, RT) and rinsed with PBS. Macrophages were incubated with Alexa Fluor® 568 phalloidin (A12380, Thermo Fisher) (20 min, RT), rinsed in cold PBS and blotted (30 min, RT) with nuclei counterstained with 4',6diamidino-2-phenylindole (DAPI) (Thermo Fisher). Sections were rinsed with cold PBS and mounted with ProLong® Gold reagent (Thermo Fisher). Slides were examined using a FluoView FV1000 confocal immunofluorescence microscope (Olympus). Non-infected macrophages were prepared in parallel as negative controls. Stacks of $10 \mathrm{z}$-plane images $(1 \mathrm{~mm}$ apart) were captured to verify the intracellular location of MAP. The number of intracellular GFP MAP per macrophage was calculated as the ration of the green mean fluorescence intensity (MFI) (i.e., MAP)/DAPI (nucleus) positive cells. At least 5 randomly chosen images were counted from each treatment. A Java-based image processing program (ImageJ, National Institutes of Health) was used for image analysis (Schneider et al. 2012; Rueden et al. 2017).

\section{MAP burden}

MAP clearance in macrophages stimulated with cathelicidins was determined by MAP F57 gene quantification. Bacterial DNA was extracted from culture medium $(175 \mu \mathrm{L})$ from macrophages stimulated with synthetic recombinant LL-37 (H6224, Bachem) (10 $\mu \mathrm{M} ; 1 \mathrm{~h})$ or inert control, washed several times in sterile PBS and challenged with MAP (MOIs 1 and 5) for up to $24 \mathrm{~h}$ at $37{ }^{\circ} \mathrm{C}$ in a humidified environment $\left(95 \% \mathrm{O}_{2}\right.$ and $\left.5 \% \mathrm{CO}_{2}\right)$. Bacterial DNA was extracted using a total nucleic acid isolation kit (MagMAX, Applied Biosystems) and stored at $-20{ }^{\circ} \mathrm{C}$ until assayed. MAP was quantified by duplex qPCR targeting the MAP- F57 region and an internal amplication control with specific primers and probes (Slana et al. 2008). qPCR run was performed using a CFX96 thermocycler (Bio-Rad). Samples were run in duplicate. A plasmid standard curve containing the single copy F57 region cloned into pCR 2.1 cloning vector (Invitrogen) was used to estimate the amount of MAP (Slana et al. 2008).
Plasmid concentration was estimated using Qubit Fluorometric Quantification (Invitrogen).

To assess direct microbicidal effects of cathelicidins, MAP $\left(10^{5} \mathrm{CFU} / \mathrm{mL}\right.$ ) was incubated with synthetic LL-37 (up to $50 \mu \mathrm{M})$ for $2 \mathrm{~h}$ at $37{ }^{\circ} \mathrm{C}$ in a humidified environment $(95 \%$ $\mathrm{O}_{2}$ and $\left.5 \% \mathrm{CO}_{2}\right)$. Escherichia coli $\left(10^{5} \mathrm{CFU} / \mathrm{mL}\right)$ was used as a control known cathelicidin susceptible bacteria. Bacteria viability survival was evaluated with rapid epifluorescence live/dead staining (BacLight ${ }^{\mathrm{TM}}$, Thermo Fisher) in a fluorescent microscopy and quantified by ImageJ.

\section{Gene expression of cytokines and host defense peptides in macrophages}

Relative transcriptional messenger gene (mRNA) expression of pro-inflammatory cytokines, (TNF- $\alpha$, IL- 8, IFN- $\gamma$, IL- $1 \beta$, IL-10), host defense peptides ( $\beta$-defensin DEF4, cathelicidin CAMP), and TLRs (2 and 4) from macrophages were quantified by real-time quantitative PCR (RT qPCR) using a CFX-96 real-time PCR system (Bio-Rad). Total RNA from cells was isolated using TRIzol reagent (15596018, Invitrogen, Thermo Fisher). Complementary DNA (cDNA) was prepared from $1 \mu \mathrm{g}$ of total RNA using Moloney murine leukemia virus reverse transcriptase (qScript cDNA synthesis; 101414-098 Quantabio). Quality and quantity of resulting RNA and cDNA were determined using a NanoVue Spectrophotometer (GE Healthcare). Each reaction mixture contained $100 \mathrm{ng}$ of cDNA, 1X SsoAdvanced Universal SYBR Green Supermix (Bio-Rad), and $0.5 \mu \mathrm{M}$ of each specific prim$\mathrm{er}$, in a final volume of $10 \mu \mathrm{L}$. Mouse primers for TNF- $\alpha$ (PPM03113G), IL-8 (CXCL1; PPM03178F), IFN- $\gamma$ (PPM03121A), IL-1 $\beta$ (PPM03109F), IL-10 (PPM03017C), $\beta$-defensin 4 (DEF4) (PPM36469A), CAMP (PPM25023A), TLR-2 (PPM04220B), TLR-4 (PPM04207F), and glyceraldehyde-3-phosphate dehydrogenase (GAPDH) (PPM02946E) ( $\mathrm{RT}^{2}$ qPCR Primer Assay, Qiagen) were used. Reaction mixtures were incubated for $95{ }^{\circ} \mathrm{C}$ for $5 \mathrm{~min}$, followed by denaturation for $5 \mathrm{~s}$ at $95{ }^{\circ} \mathrm{C}$ and combined annealing/extension for $10 \mathrm{~s}$ at $60{ }^{\circ} \mathrm{C}$ (total of 40 cycles). Negative controls for cDNA synthesis and PCR procedures were consistently included. The RT-qPCR efficiency for all the primer sequences was previously verified (nearly 100\%) from the slope in a linear regression model according to the equation: efficiency $=10(-1 /$ slope $)-1$ in agreement with the MIQE guidelines (Bustin et al. 2009). $R^{2}$ values were calculated using 10-fold serial dilutions of cDNA. Values of target mRNA were corrected relative to the housekeeping gene coding GAPDH. Non-infected and untreated (no cathelicidin) cells were used as controls for qPCR. Data were analyzed using the $2^{-\Delta \Delta C T}$ method and results reported as mean fold change of target transcription levels. 


\section{Protein determination of cytokines and TLRs in macrophages}

Concentrations of secreted TNF- $\alpha$, IL- 8 , and INF- $\gamma$ proteins in supernatants of macrophages exposed to MAP were determined with a mouse cytokine assay (Quantikine® ELISA, $\mathrm{R} \& D)$. Absorption data, read at 450/540 nm, with background absorption taken into account, were plotted on a standard curve to obtain corresponding concentrations.

Intracellular protein levels of TLR-2 was determined by western blotting in macrophages exposed to MAP. Cells were lysed in denaturing cell extraction buffer (DCEB; Invitrogen) and the protein concentrations determined by BCA assays (Pierce BCA protein assay kit, Thermo Scientific). Each sample (15 $\mu \mathrm{g}$ protein) was mixed 1:1 with Laemmli sample buffer and separated on $10 \%$ SDS-PAGE gels. Proteins were transferred onto a PVDF membrane (Bio-Rad) activated with methanol. The membrane was blocked (1 h, RT) with 5\% skim milk powder dissolved in Tris-buffered saline plus 0 . $1 \%$ Tween 20 solution (TBST). Membranes were probed (overnight, $4{ }^{\circ} \mathrm{C}$ ) with anti-murine TLR-2 (E1J2W, 13744, Cell Signaling Technology; 1:1000) or antiGAPDH (CB1001, Calbiochem; 1:1000) antibodies. After incubation ( $2 \mathrm{~h}, \mathrm{RT})$ with a horseradishperoxidase conjugate secondary anti-mouse antibody (115-035-146, Jackson ImmunoResearch; 1:10,000), blots were developed (Clarity Western ECL Detection System, Bio-Rad). The image captures and densitometric analyses were performed with the ChemiDoc MP Imaging system and ImageLab $4 \cdot 0 \cdot 1$ software (BioRad), respectively. Normalization was done with reference to the GAPDH lane protein. Results are reported as mean fold change of target expression in infected groups compared with an uninfected control group.

\section{Cytotoxic effect on macrophages exposed to MAP and cathelicidins}

A lactate dehydrogenase (LDH) assay was performed on macrophages stimulated with cathelicidin and infected with MAP (Pierce $^{\mathrm{TM}}$ LDH Cytotoxicity Assay Kit, Thermo Fisher) to determine cell survival. Optical density readings (490/ $680 \mathrm{~nm}$ ) were converted to LDH microunits, based on a standard curve.

\section{Statistical analyses}

Analytical data represented as histograms were recorded as mean values with bars representing standard errors of the mean (SEM) from a minimum of two independent experiments, with data obtained in triplicates, unless otherwise mentioned. Normality was assessed using D'Agostino \& Pearson omnibus normality or Shapiro-Wilk (Royston) tests. All comparisons were performed using either two-sided unpaired Student's $t$ test (treated versus control) or one-way analysis of variance (ANOVA) with a post hoc Bonferroni correction for multiple group comparisons. All statistical analyses were performed with GraphPad Prism software (GraphPad 7.0). $p<0.05$ was considered significant.

\section{Results}

\section{MAP rapidly colonized murine macrophages}

Rapid internalization of MAP was shown in macrophages challenged by MAP that expressed green fluorescent protein (GFP). The A1 157 GFP-MAP was identified in the cytoplasm of macrophages, contained within actin boundaries, as early as $3 \mathrm{~h}$ (Fig. 1a-h) and persisted until $24 \mathrm{~h}$ postinfection. An intracellular MAP distribution throughout the cell cytoplasm as intact bacillus once engulfed by macrophages was confirmed by X-Z-stack images (Fig. $1 \mathrm{~h}$ and i). A quickly $(3 \mathrm{~h}$ ) internalization of MAP into J774.A1 cells was further verified in a genetical similar MAP strain (K-10; pWes4) (Suppl Fig. 1). Taken togheter, we confirmed this murine phagocytic cell line is susceptible to MAP infection and that A1 157 MAP transformation with GFP plasmid did not affects its invasive virulence.

\section{Synthetic LL-37 reduced MAP presence within macrophages}

It has been demonstrated that exogenous cathelicidin (LL-37) reduces intracellular survival of $M$. smegmatis, M. tuberculosis, and M. bovis BCG in macrophages (Sonawane et al. 2011); however, antibacterial effect of cathelicidin on MAP has not been reported. We found macrophage pretreated with increased doses of synthetic recombinant LL-37 showed decreased intracellular presence of MAP (MOI 1) at 3 (Fig. 2 a-a", b-b"', c-c"”, and $\mathrm{d}-\mathrm{d}$ "') and $24 \mathrm{~h}$ postinfection. This reduced MAP presence into macrophages stimulated by cathelicidin (i.e., reduced MFI green fluorescence MAP intensity per macrophage) was significant with higher doses of LL-37 $(5$ and $10 \mu \mathrm{M})$ at $3 \mathrm{~h}$ postinfecction $(p<0.05)$ (Fig. 2e). Reduced intracellular MAP in macrophages stimulated by cathelicidin was confirmed by the quantification of MAP (F57) DNA. MAP burden was lesser in macrophages pretreated with LL-37 with significant differences for high MAP challenge (MOI 5) at 3 and $24 \mathrm{~h}$ postinfection $(p<0.05)$ (Fig. 3a).

To understand the reduced MAP burden in macrophages stimulated by cathelicidins, a direct microbicidal effect of the 


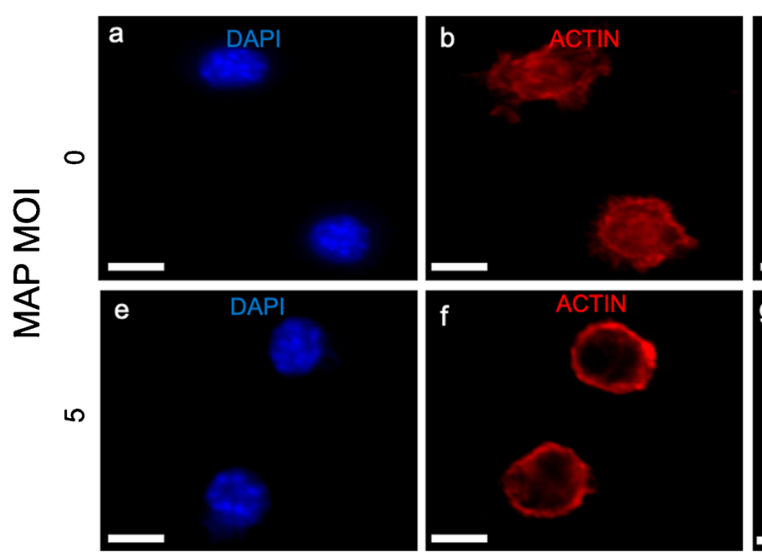

Fig. 1 MAP was immunolocalized inside macrophages. a-d GFP-MAP (A1 157) (green) (MOI 5) was identified by confocal immunofluorescence in murine macrophages at $3 \mathrm{~h}$ in comparison to control MOI 0. Macrophages were counterstained with phalloidin, which binds actin cytoskeleton (red) and DAPI as a nucleus maker

peptide was investigated by live/dead bacterial viability staining. Synthetic LL-37 at a dose of $10 \mu \mathrm{M}$ did not kill MAP whereas high dosage of cathelicidin $(50 \mu \mathrm{M})$ revealed some bactericidal effect on MAP $(\approx 50 \%)$ (Fig. $3 \mathrm{~b})$. Same cathelicidin doses $(10$ and $50 \mu \mathrm{M})$ killed $(>90 \%)$ E. coli, a known cathelicidin susceptible bacteria (data not shown). The doses used of synthetic LL-37 (up to $50 \mu \mathrm{M}$ ) did not cause
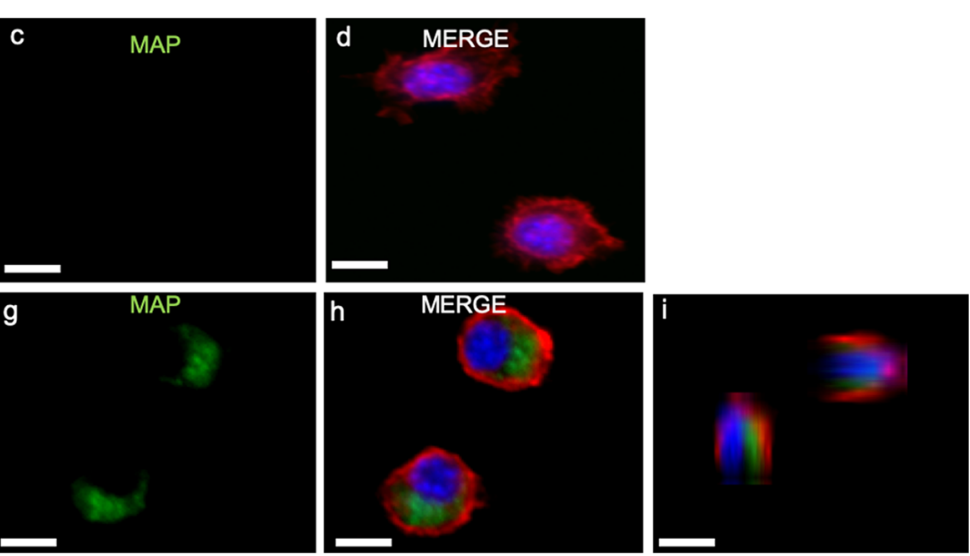

(blue). Representative images for 3 independent experiments. Scale bar $=50 \mu \mathrm{m}$. e-i Internalization of MAP within macrophages. The enclosed dashed rectangle represents a higher magnification of a $x-z-$ plane image (a stacks of 10 images $1 \mathrm{~mm}$ apart). Scale bar $=50 \mu \mathrm{m}$

macrophage cell damage or death as determined by the microscopical observation of healthy macrophages (Suppl Fig. 2ab"') and a insignificant LDH release compared to control (Suppl Fig. 2c) after infection with MAP (A1 157, MOIs 1 and 5) for up to $24 \mathrm{~h}$. These studies confirmed cathelicidin reduces the MAP load in macrophages, albeit without killing the host cell or directly killing the bacterium.
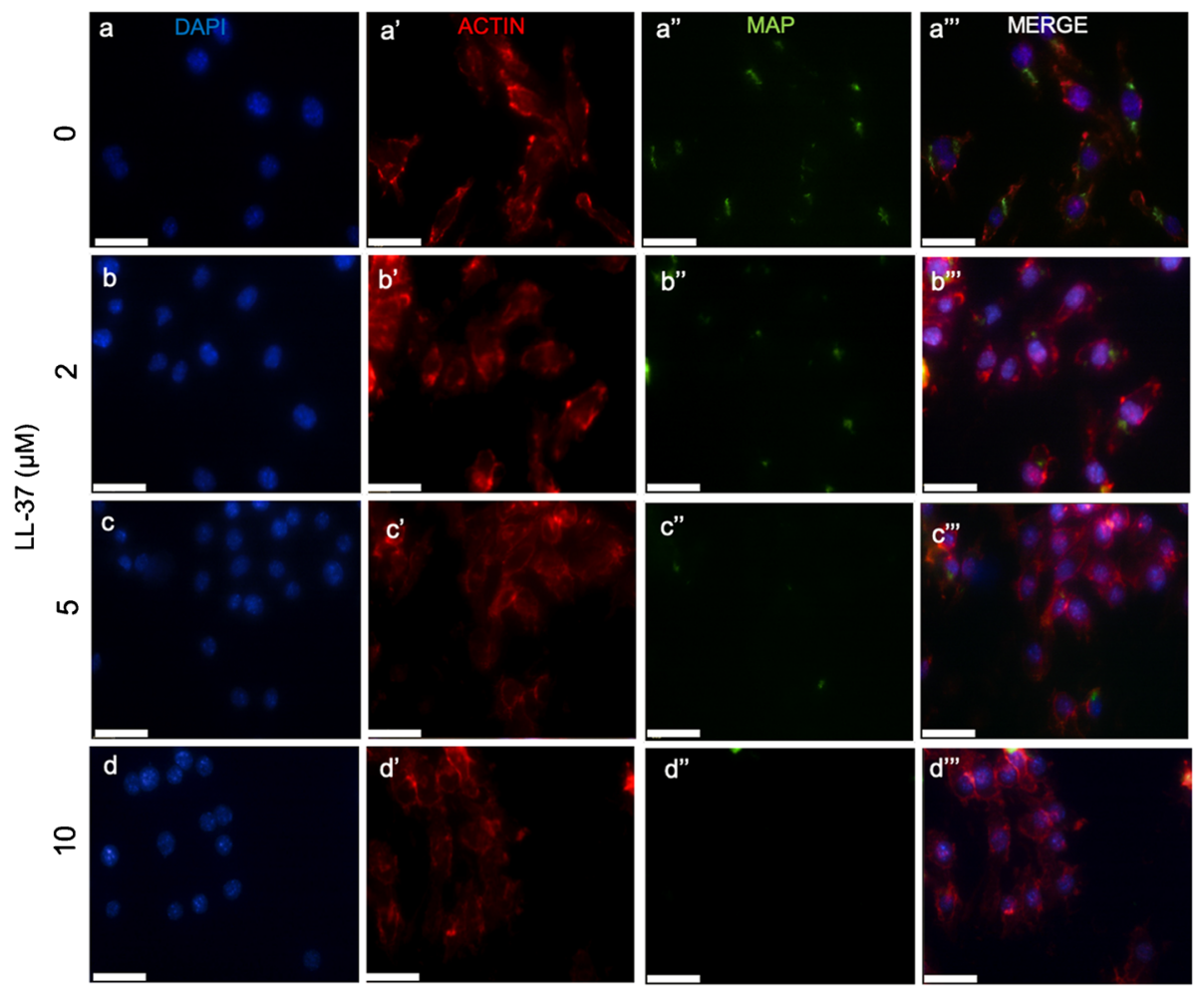

independent experiments. Scale bar $=100 \mu \mathrm{m}$. (e) Mean fluorescence intensity (MFI) of MAP internalized in macrophages pretreated with cathelicidins. MFI was calculated as the ration between GFP-MAP (green) fluorescence MAP intensity/number of macrophages (5 fields/ treatment; $n=3$ independent experiments done in triplicate). ${ }^{*} p<0.05$
Fig. 2 (a-d"') Pretreatment with LL-37 cathelicidins reduced GFP-MAP burden in macrophages. GFP-MAP (K10) (green) was cultured with macrophages pretreated with LL-37 (up to $10 \mu \mathrm{M} ; 1 \mathrm{~h}$ ) for $3 \mathrm{~h}$. Macrophages were counterstained with phalloidin, which binds actin (red) and DAPI as a nucleus marker (blue). Representative images for 3

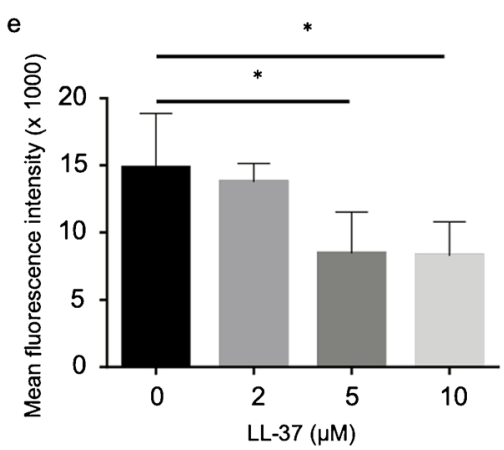


a

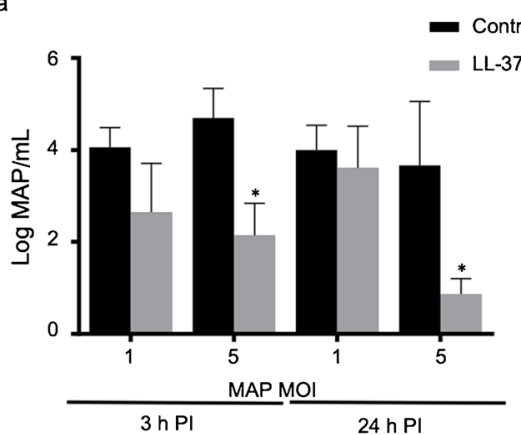

b

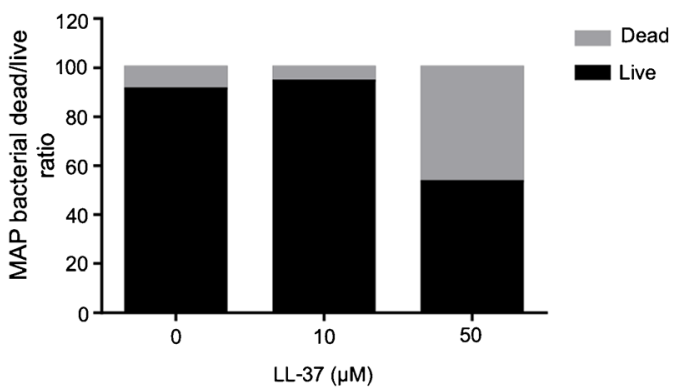

$\mathrm{LL}-37(\mu \mathrm{M})$

10
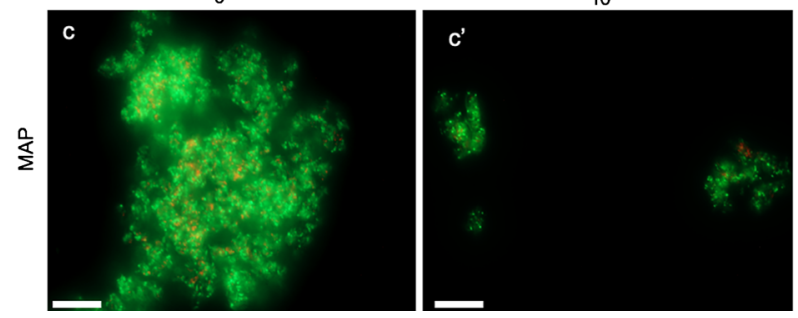

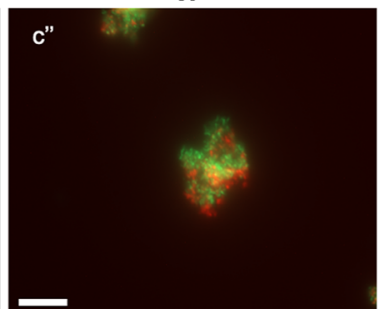

Fig. 3 Cathelicidin LL-37 reduced quantitative burden of MAP. (a, b) MAP DNA was quantified by qPCR in macrophages stimulated with synthetic LL-37 $(10 \mu \mathrm{M} ; 1 \mathrm{~h})$ and challenged with MAP (MOIs 1 and 5) for up to $24 \mathrm{~h}$. The estimated values represent the averages for two separate qPCR experiments targeting MAP F57 DNA. (c-c") Live MAP $\left(10^{5} \mathrm{CFU} / \mathrm{mL}\right.$ ) was directly incubated with synthetic LL37 (up to $50 \mu \mathrm{M}$;

\section{LL-37 modulated early synthesis of pro-inflammatory cytokines in macrophages challenged by MAP}

Macrophages exposed to inflammatory stimuli secrete a signature array of pro-inflammatory cytokines, including IFN- $\gamma$, IL-8, TNF- $\alpha$, and IL- $1 \beta$, which increase vascular permeability and recruit inflammatory cells to the site of infection (Janeway and Medzhitov 2002; Boucher et al. 2018). MAP infection induces in vitro strong production of IFN- $\gamma$ and TNF- $\alpha$ in human (THP-1) macrophages (Wang et al. 2014). We showed that whereas MAP induced transcriptional mRNA synthesis of TNF- $\alpha$ in murine macrophages (peak with MOI $5 ; 3$ h) ( $p<0.05$, Fig. 4a, b), pretreatment with synthetic LL37 reduced TNF- $\alpha$ synthesis in response to live MAP (MOI 5; 3 and $24 \mathrm{~h}$ ) ( $p<0.05$, Fig. 4a, b). Moreover, concentrations of secreted TNF- $\alpha$ were lower in macrophages exposed to MAP and pretreated with LL-37 (385 and $957 \mathrm{pg} / \mathrm{mL}$ at 3 and $24 \mathrm{~h}$, respectively) than in challenged macrophages without cathelicidins (464 and 1193 pg/mL; Fig. 4c, d).

Directional movement of leukocytes into the site of infection is mostly regulated by a $\mathrm{C}-\mathrm{X}-\mathrm{C}$ motif containing chemokine ligand 8 (CXCL8; IL-8) (Janeway and Medzhitov 2002). Thus, we determined whether exogenous cathelicidins modulated neutrophil factor IL-8 synthesis in macrophages as a defensive mechanism. MAP induced a delayed IL-8 transcriptional gene response (MOI 5; $24 \mathrm{~h}$ ); this was further increased by pretreatment with synthetic LL-37 (MOI 5, mostly at $24 \mathrm{~h}$ )
$2 \mathrm{~h}$ ) or inert control solution. Fluorescent microscopic images were taken from representative cathelicidin treated and untreated bacteria subjected to live (green) or dead/damaged (red) by a bacterial viability assay (Live/Dead Backlight (C) stain). Scale bar $=100 \mu \mathrm{m}$. Relative ratio of live/dead bacteria were quantified from 5 different images using ImageJ

as compared to untreated MAP-infected macrophages ( $p<0.05$, Fig. 4e, f). LL-37 induced slight decrease in IL-8 transcriptional gene in macrophages challenged with low MAP doses (MOI 1) ( $p>0.05$; Fig. 4e, f). The levels of secreted IL-8 were not significant different among treatments (Fig. 4g, h).

Cellular responses induced by IFN- $\gamma$ (e.g., autophagy, lysosomal degradation) are indispensable for resistance to intracelullar pathogens, including MAP (Burger et al. 2018). In the present study, pretreatment with LL-37 in MAPinfected macrophages reduced IFN- $\gamma$ transcriptional gene expression to baseline levels (MOI 1; $3 \mathrm{~h} ; p<0.05$, Fig. 5a). Only a slight transcriptional IFN- $\gamma$ gene downregulation was observed in macrophages pre treated with LL-37 $(2 \mu \mathrm{M})$ and challenged with high MAP doses (MOI 5 at $3 \mathrm{~h}$ and $24 \mathrm{~h}$ ) ( $p>0.05$; Fig. 5a, b). The levels of secreted IFN- $\gamma$ were undectable (data not shown).

Endogenous IL-1 $\beta$, cleaved by cytosolic caspases to form mature IL-1 $\beta$ that promotes inflammation and apoptosis (Janeway and Medzhitov 2002) and IL-10, an antiinflammatory cytokine that decreased ability of macrophages to kill MAP (Weiss et al. 2005), are hallmark cytokines during paratuberculosis. IL-1 $\beta$ was increased at gene transcription levels in MAP-infected macrophages in the first $24 \mathrm{~h}$ but cathelicidin pretreatment had no effect (Suppl Fig. 3a-b). IL10 remained unaltered after cathelicidin and/or MAP challenge (Suppl Fig. 3c-d). Host defense peptides, e.g., $\beta$ - 

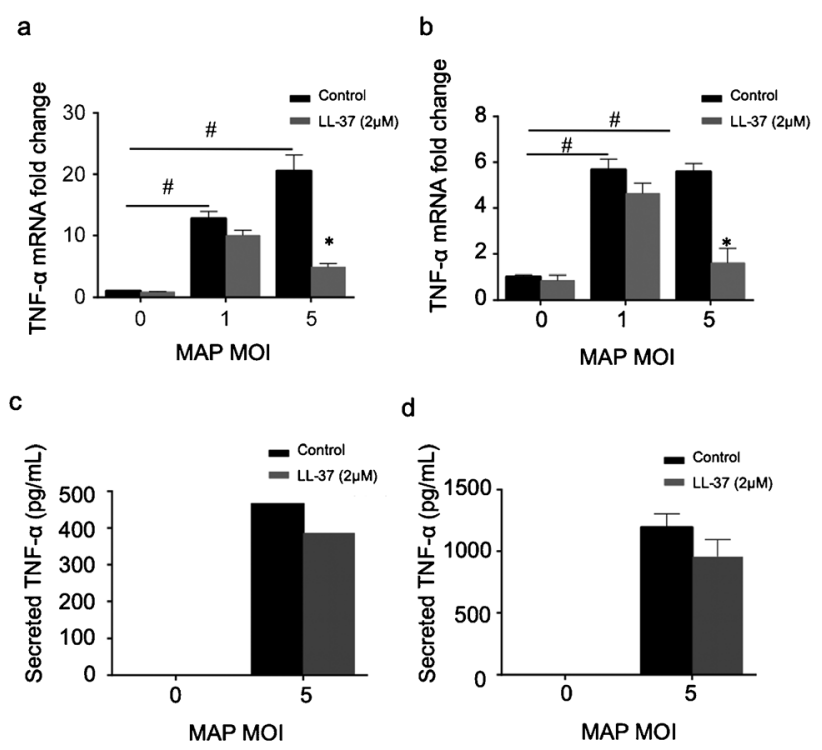

d

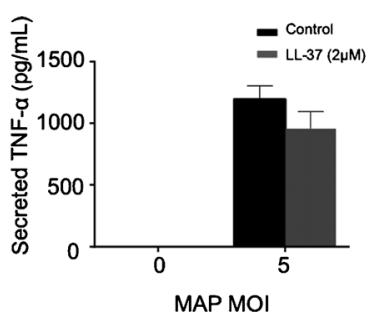

$3 \mathrm{~h}$

$24 \mathrm{~h}$

\section{MAP infection}

Fig. 4 Cathelicidin LL-37 modulated the production of TNF- $\alpha$ and IL-8 on macrophages infected by MAP. Transcriptional gene expression and secretion of TNF- $\alpha(\mathbf{a}-\mathbf{d})$ and IL-8 (e-h) were determined in MAPinfected macrophages pretreated with LL-37 $(2 \mu \mathrm{M} ; 1 \mathrm{~h})$. Expression of

defensins and cathelicidins, are of importance due to their ability to kill invading pathogens and to modulate immune defenses (Zanetti 2005; Cobo et al. 2015, 2017). However,
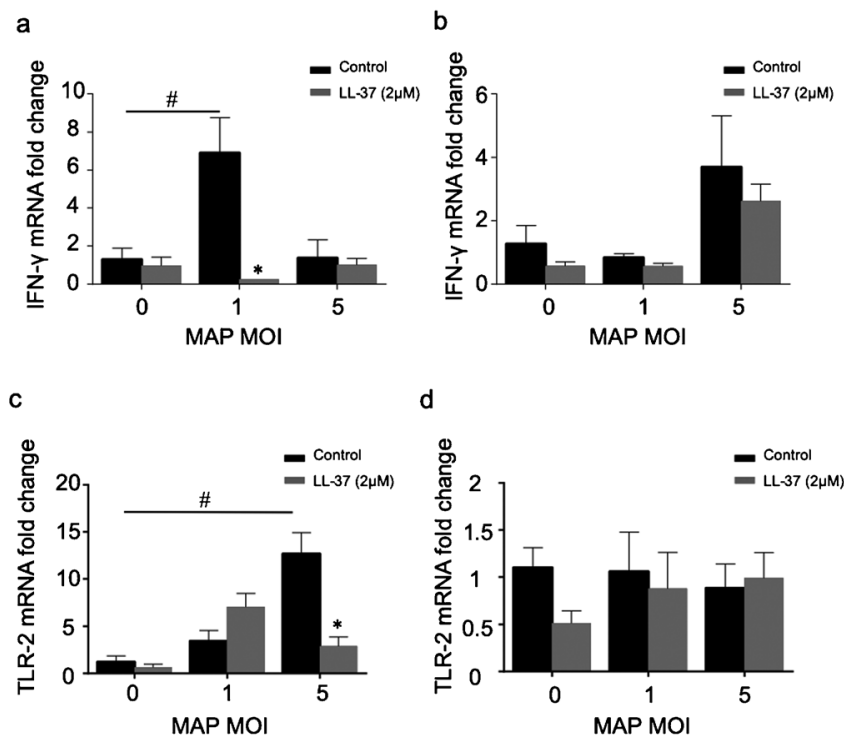

$3 \mathrm{~h}$

$24 \mathrm{~h}$

\section{MAP infection}

Fig. 5 Expression of IFN- $\gamma$, TLR-2, and TLR-4 on macrophages infected by MAP pretreated with cathelicidin LL-37. Transcriptional gene/protein expression of IFN- $\gamma(\mathbf{a}, \mathbf{b})$, TLR-2 (c-e), and TLR-4 (f, g) was determined in MAP-infected macrophages (for 3 and $24 \mathrm{~h}$ postinfection) pretreated with LL-37 $(2 \mu \mathrm{M} ; 1 \mathrm{~h})$. Expression of mRNA
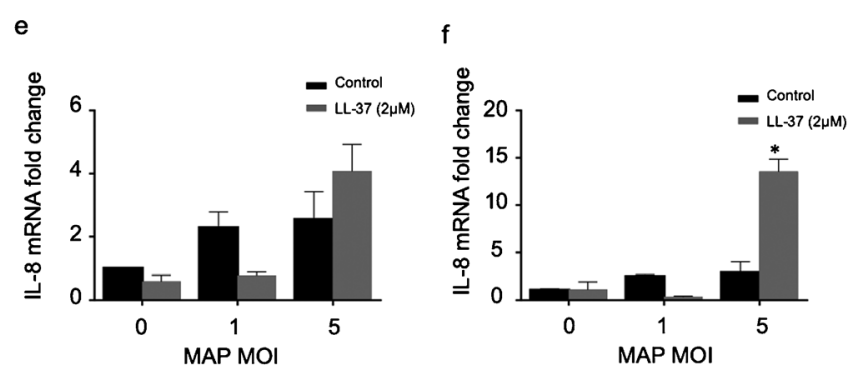

g

n

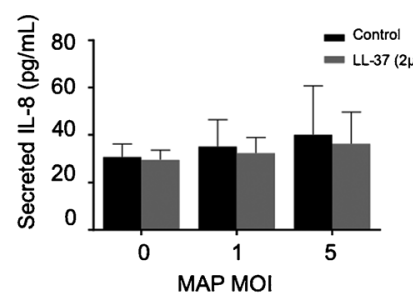

$3 \mathrm{~h}$

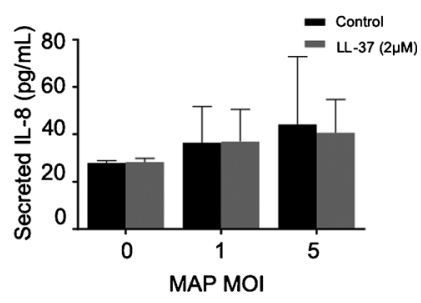

$24 \mathrm{~h}$
MAP infection

mRNA was quantified with qRT-qPCR. Secreted proteins were determined with ELISA. Means \pm SEM are shown $(n=3$ independent experiments done in triplicate). $* p<0.05$ compared to the untreated control at same MOI. $\# p<0.05$ compared with MOI 0

MAP did not induce endogenous transcriptional gene expression of $\beta$ defensin- 4 and CAMP in macrophages during the first 24 h (Suppl Fig. 3e-f). Taken together, cathelicidin

$f$ f
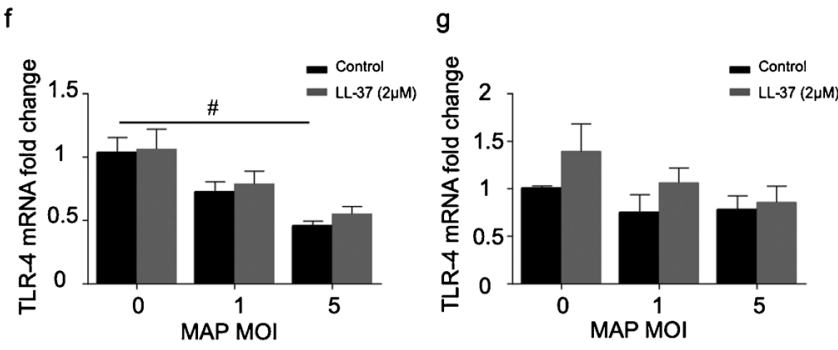

e

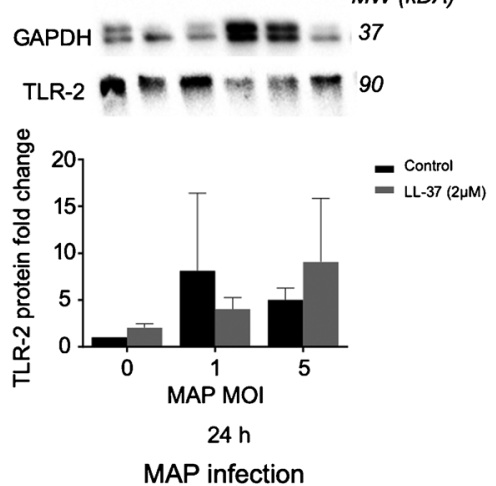

was quantified with RT-qPCR. Proteins were determined with western blotting for TLR-2. Means + SEM are shown $(n=3$ independent experiments done in triplicate). $* p<0.05$ compared to the untreated control at same MOI. \#p $<0.05$ compared with MOI 0 
stimulation induced macrophages to produce less proinflammatory TNF- $\alpha$ and IFN- $\gamma$ but increased IL- 8 when invaded by MAP.

\section{LL-37 downregulated expression of TLR-2 in macrophages infected by MAP}

Signaling through TLR-2 and TLR-4 regulates phagosome trafficking and antimicrobial and inflammatory responses in mononuclear phagocytes infected by MAP (Lee et al. 2014; Weiss et al. 2008). Herein, MAP quickly (MOI 5; 3 h) induced higher transcriptional gene expression of TLR-2 in macrophages ( $p<0.05$, Fig. $5 c$, d). This TLR-2 gene response was abolished by pretreatment with synthetic LL-37 ( $p<0.05$; Fig. $5 c)$. No TLR-2 response or cathelicidin effect was noticed at later points after MAP challenge (MOI 1, 24 h) (Fig. 5d). Effects on TLR-2 in macrophages by MAP or LL-37 did not correspond to significant variations in the total level TLR-2 protein ( $p>0.05$ Fig. 5e). For TLR4, mRNA transcription was reduced in macrophages during early MAP infection (MOI 5, $3 \mathrm{~h})(p<0.05$, Fig. 5 f, g) and only a slight TLR4 gene upregulation was observed in LL-37 pretreate cells MAP (MOI 1 and 5 , at 3 and 24 h) ( $p>0.05$; Fig. 5f, g).

\section{Discussion}

In this study, synthetic human cathelicidin LL-37 reduced intracellular burden of MAP in macrophages and mitigated production of pro-inflammatory cytokines, likely by impairing TLR-2 signaling. This occurred in murine J774A.1 macrophages, a cell line receptive to intracellular mycobacterias, including MAP (Hostetter et al. 2003; Zur Lage et al. 2003) as well as M. avium and M. tuberculosis (Anes et al. 2003). Whereas high doses (i.e., MOI 10) (Kuehnel et al. 2001; Hostetter et al. 2003; Lamont et al. 2013, 2014; Bannantine et al. 2015) and lower doses (MOI 1 and 5) (Periasamy et al. 2009; Donnellan et al. 2017) of MAP are biologically relevant and had been tested in murine (J774A.1) macrophages and cultured bovine monocyte-derived macrophages, lower MAP challenge was choosen to better represent early natural infection and detect host cells innate reponses to exogenous cathelicidin.

Effects of cathelicidin controlling mycobacterial infections in macrophages have been reported. Endogenous overexpression of murine cathelicidin and synthetic human LL-37 (and derived LLKKK-18) increased intracellular killing of M. smegmatis, M. bovis, and M. tuberculosis in murine macrophages (Sonawane et al. 2011). However, the antibacterial effect of LL-37 on MAP described here is novel. We found synthetic LL-37 at doses (up to $10 \mu \mathrm{M}$ ) below half-maximal inhibitory concentration $\left(\mathrm{IC}_{50}\right)$ (Sonawane et al. 2011) reduced MAP burden in macrophaghes as detected by MAP specific qPCR counting and internalized MAP by confocal microscopy. Moreover, we demonstrated that this cathelicidin dose (up to $10 \mu \mathrm{M}$ ) has no relevant direct anti-mycobacterial effects on MAP. This finding suggests an immunomodulatory role of exogenous LL-37 increasing the antibacterial defenses in macrophages. Such immunomodulatory effects of low doses of LL-37 have been reported. For instance, low LL-37 dosage $(<1 \mu \mathrm{M})$ inhibited TNF- $\alpha$ release from LPS-induced macrophages (Mookherjee et al. 2006). Noteworthy, the tested LL-37 concentrations were physiologic, similar to those found in mucosal surfaces in humans $(0.5-4 \mu \mathrm{M})$ (Schaller-Bals et al. 2002), suggesting this function of cathelicidins modulating macrophage behavior may occur in natural conditions. Higher doses of LL-37 (> 5, up to $20 \mu \mathrm{M}$ ) have been found also detrimental for mycobacteria (Sonawane et al. 2011), and we showed LL-37 at $50 \mu \mathrm{M}$ directly killed some MAP. However, such high doses of cathelicidin with direct killing effect may concur with cytotoxic side outcomes. Thus, the role of cathelicidin stimulating macrophage functions rather than bactericidal effects is of special interest in developing new anti-infectious therapeutics. Regarding naturally occurring host defense peptides, transcriptional gene levels of cathelicidins and related host defense $\beta$-defensin in macrophages did not change during the first $24 \mathrm{~h}$ after MAP infection. In contrast, other mycobacteria, M. smegmatis and M. bovis (BCG), upregulated endogenous synthesis of cathelicidins in murine macrophages as early as 1 to $3 \mathrm{~h}$, followed by a rapid decrease after $24 \mathrm{~h}$ (Sonawane et al. 2011). MAP may require longer exposure to induce endogenous cathelicidin-coding gene expression in macrophages or MAP has pathogenic mechanisms to prevent effective innate immune responses.

TLR-2 is key in mycobacterial pathogenesis; it may facilitate engulfment of the bacterium into the cytosol (Fournier 2013) and trigger production of pro-inflammatory cytokines/ chemokines and reactive oxygen species (Yang et al. 2009). In the present study, exogenous LL-37 downregulated the early gene expression of TLR-2 in murine macrophages with no detectable changes in total TLR-2 protein. Reduced TLR-2 availability in macrophages exposed to exogenous cathelicidins may be responsible for impaired engulfment of MAP and thus indirectly reduce immune inflammatory responses, although the surface protein variations may not be noticed by western blotting. Mycobacterial cell wall lipoproteins such as mannosylated lipoarabinomannan may be TLR2 agonists (Gomes et al. 2008) and initiate signaling though the MAPK-p38 pathway (Arsenault et al. 2014). In fact, a specific lipopeptide $(19 \mathrm{kDa})$ isolated from M. tuberculosis stimulated TLR-2 in macrophages and up-regulated expression of vitamin $\mathrm{D}$ receptor, leading to cathelicidin synthesis and killing of intracellular mycobacteria (Liu et al. 2006). Furthermore, TLR-2 signaling promoted endogenous cathelicidin gene expression in murine bone marrow-derived macrophages exposed to M. avium (Santos et al. 2014) and in 
human macrophages (THP-1) challenged by M. tuberculosis (Yang et al. 2009). Equally important for MAP signaling, TLR-4 has been implicated in pro-inflammatory cytokine production during MAP infection in human and murine macrophages (Ferwerda et al. 2007) and antigen-presenting cells (Lee et al. 2014). However, our study did not find TLR-4 gene expression modification by synthetic cathelicidins. Dysregulated expression of TLR-2 and TLR-4 (i.e., polymorphisms or mutations) made cattle more susceptible to Johne's disease (Mucha et al. 2009). Thus, the proposed role of synthetic LL-37 modulating certain TLRs in macrophages during MAP infection (e.g., TLR-2) may have therapeutic potential in genetically vulnerable cattle.

Increased production of TNF- $\alpha$ in response to MAP occurs in a range of cells, including bovine macrophages (Colavecchia et al. 2016), human macrophages and epithelial cells (Wang et al. 2014), and murine dendritic cells (Lee et al. 2014). Exaggerated secretion of TNF- $\alpha$ contributes to inflammatory damage during MAP infection, including granuloma formation in the ileum (portal of entry for mycobacteria) and in wasting disease (Adams and Czuprynski 1994). Moreover, anti-TNF- $\alpha$ therapeutics for treating related chronic diseases (Crohn's disease) are associated with lesser mucosal inflammation and granuloma formation (Berns and Hommes 2016). In the present study, we found cathelicidin significatively reduce TNF- $\alpha$ mRNA and slightly secreted protein levels. Differences in cytokine kinetic between gene transcription and protein synthesis are indicative that longer exposure with cathelicidins (or higher doses) may be needed to suppress the protein synthesis. This cathelicidin-driven anti-TNF- $\alpha$ effect may have clinically relevant anti-inflammatory activity in Johne's disease, reducing tissue damage induced by MAPactivated macrophages. Another key pro-inflammatory cytokine, IFN- $\gamma$, was also disminished by exogenous cathelicidin in macrophages infected with MAP. There was synergy between IFN- $\gamma$ and TLR-2 ligands to upregulate cathelicidin expression in human monocytes and macrophages (Rode et al. 2017). Consequently, suppression of IFN- $\gamma$ and TLR-2 gene expression by exogenous LL-37 could prevent endogenous cathelicidin production. In addition, reduced TNF- $\alpha$ production in macrophages treated with LL-37 may further contribute to reduced synthesis of endogenous cathelicidin, as TNF- $\alpha$ knockdown mice infected with M. avium had reduced cathelicidin expression (Santos et al. 2014).

In the present study, MAP induced IL- 8 in macrophages, whereas LL-37 caused further increases in macrophagederived IL-8 mRNA. Increases in secreted IL- 8 protein levels may need longer or higher doses of cathelicidins, or this macrophage type model secretes limited amount of proinflammatory cytokines. In agreement, synthetic LL-37 increased synthesis of IL-8 in colonic epithelial cells exposed to Gram-negative bacteria (Marin et al. 2017), whereas MAP rapidly induced macrophage-derived IL-8 (Weiss et al. 2005).
Chemokine IL-8, a neutrophil factor expressed by both hematopoietic (neutrophils and macrophages) and nonhematopoietic cells, promotes rapid migration of leukocytes into an infected site and aids pathogen elimination. Consequently, LL-37 may confer protection against MAPrelated diseases by inducing IL-8 and chemoattracting lymphocytes and neutrophils to the site of infection.

In conclusion, synthetic LL-37 cathelicidin limited MAP invasion in macrophages by downregulating expression of TLR-2 and decreasing synthesis of TNF- $\alpha$, IFN- $\gamma$, and IL- 8 , hallmarks of gut inflammation in Johne's disease. In the absence of effective anti-MAP therapeutics and limited success of vaccine development (Barkema et al. 2018), this study yielded new knowledge regarding pathogenesis of MAP infection and potential antibacterial and anti-inflammatory roles of synthetic cathelicidins. Administration of exogenous cathelicidins when endogenous production is not sufficient or impaired, due to a pathogen-evasion mechanism, may promote defensive mechanisms on macrophages against mycobacteria. The therapeutic use of cathelicidins to prevent diseases, such as Johne's disease, still remains unknown. Whereas our study in a murine macrophage line indicates cathelicidin may prevent MAP infection, protective effects of cathelicidins need to be confirmed in the natural host (e.g., bovine macrophages).

Acknowledgments Immunofluorescence studies were conducted in the Live Cell Imaging Facility, Snyder Institute, University of Calgary.

Author contributions $\mathrm{KC}$ acquired and analyzed all the data. PL and YT conducted the monocyte culture and qPCR data. RH conducted the macrophage imaging. RA created MAP A1-157 GFP, performed MAP culture and $\mathrm{qPCR}$ and live/dead assays. RA, JB, and HB provided critical scientific input. $\mathrm{KC}$ and $\mathrm{EC}$ conceived the experiment and wrote the manuscript.

Funding This work was supported by the Margaret Gunn Endowment for Animal Research (UofC), NSERC Discovery (RGPAS-2017-507827) to EC and by the BEC.AR (Program for short term internship in biotechnology and agro-industry in BID country members sponsored by the Ministry of Education, Argentina) to KC.

\section{Compliance with ethical statements}

Conflict of interest The authors declare that they have no conflicts of interest.

Ethical approval This article does not contain any studies with human participants or animals performed by any of the authors.

\section{References}

Adams JL, Czuprynski CJ (1994) Mycobacterial cell wall components induce the production of TNF-alpha, IL-1, and IL- 6 by bovine monocytes and the murine macrophage cell line RAW 264.7. Microb Pathog 16:401-411 
Ahlstrom C, Barkema HW, Stevenson K, Zadoks RN, Biek R, Kao R, Trewby H, Haupstein D, Kelton DF, Fecteau G, Labrecque O, Keefe GP, McKenna SL, De Buck J (2015) Limitations of variable number of tandem repeat typing identified through whole genome sequencing of Mycobacterium avium subsp. paratuberculosis on a national and herd level. BMC Genomics 16:161

Ahlstrom C, Barkema HW, De Buck J (2016a) Relative frequency of 4 major strain types of Mycobacterium avium ssp. paratuberculosis in Canadian dairy herds using a novel single nucleotide polymorphism-based polymerase chain reaction. J Dairy Sci 99: 8297-8303

Ahlstrom C, Barkema HW, Stevenson K, Zadoks RN, Biek R, Kao R, Trewby H, Haupstein D, Kelton DF, Fecteau G, Labrecque O, Keefe GP, McKenna SL, Tahlan K, De Buck J (2016b) Genome-wide diversity and phylogeography of Mycobacterium avium subsp. paratuberculosis in Canadian dairy cattle. PLoS One 11:e0149017

Alonso S, Pethe K, Russell DG, Purdy GE (2007) Lysosomal killing of Mycobacterium mediated by ubiquitin-derived peptides is enhanced by autophagy. Proc Natl Acad Sci U S A 104:6031-6036

Anes E, Kuhnel MP, Bos E, Moniz-Pereira J, Habermann A, Griffiths G (2003) Selected lipids activate phagosome actin assembly and maturation resulting in killing of pathogenic mycobacteria. Nat Cell Biol 5:793-802

Arsenault RJ, Maattanen P, Daigle J, Potter A, Griebel P, Napper S (2014) From mouth to macrophage: mechanisms of innate immune subversion by Mycobacterium avium subsp. paratuberculosis. Vet Res 45: $54-54$

Bannantine JP, Stabel JR, Laws E, Cardieri MCD, Souza CD (2015) Mycobacterium avium subspecies paratuberculosis recombinant proteins modulate antimycobacterial functions of bovine macrophages. PLoS One 10:e128966. https://doi.org/10.1371/journal. pone. 0128966

Barkema HW, Orsel K, Nielsen SS, Koets AP, Rutten V, Bannantine JP, Keefe GP, Kelton DF, Wells SJ, Whittington RJ, Mackintosh CG, Manning EJ, Weber MF, Heuer C, Forde TL, Ritter C, Roche S, Corbett CS, Wolf R, Griebel PJ, Kastelic JP, De Buck J (2018) Knowledge gaps that hamper prevention and control of Mycobacterium avium subspecies paratuberculosis infection. Transbound Emerg Dis 65(Suppl 1):125-48

Berns M, Hommes DW (2016) Anti-TNF-alpha therapies for the treatment of Crohn's disease: the past, present and future. Expert Opin Investig Drugs 25:129-143

Boucher E, Marin M, Holani R, Young-Speirs M, Moore DM, Cobo ER (2018) Characteristic pro-inflammatory cytokines and host defence cathelicidin peptide produced by human monocyte-derived macrophages infected with Neospora caninum. Parasitology 145:871-884

Burger E, Araujo A, Lopez-Yglesias A, Rajala MW, Geng L, Levine B, Hooper LV, Burstein E, Yarovinsky F (2018) Loss of Paneth cell autophagy causes acute susceptibility to Toxoplasma gondii-mediated inflammation. Cell Host Microbe 23:177-190 e174

Bustin SA, Benes V, Garson JA, Hellemans J, Huggett J, Kubista M, Mueller R, Nolan T, Pfaffl MW, Shipley GL, Vandesompele J, Wittwer CT (2009) The MIQE guidelines: minimum information for publication of quantitative real-time PCR experiments. Clin Chem 55:611-622

Chiodini RJ, Buergelt CD (1993) Susceptibility of Balb/c, C57/ B6 and C57/B10 mice to infection with Mycobacterium paratuberculosis. $\mathrm{J}$ Comp Pathol 109:309-319

Cobo ER, Kissoon-Singh V, Moreau F, Chadee K (2015) Colonic MUC2 mucin regulates the expression and antimicrobial activity of betadefensin 2. Mucosal Immunol 8:1360-1372

Cobo ER, Kissoon-Singh V, Moreau F, Holani R, Chadee K (2017) MUC2 mucin and butyrate contribute to the synthesis of the antimicrobial peptide cathelicidin in response to Entamoeba histolytica- and dextran sodium sulfate-induced colitis. Infect Immun 85: e00905-16. https://doi.org/10.1128/IAI.00905-16

Colavecchia SB, Fernandez B, Jolly A, Minatel L, Hajos SE, Paolicchi FA, Mundo SL (2016) Immunological findings associated with Argentinean strains of Mycobacterium avium subsp. paratuberculosis in bovine models. Vet Immunol Immunopathol 176:28-33

Cooney MA, Steele JL, Steinberg H, Talaat AM (2014) A murine oral model for Mycobacterium avium subsp. paratuberculosis infection and immunomodulation with Lactobacillus casei ATCC 334. Front Cell Infect Microbiol 4:11.10.3389

Corbett CS, Barkema HW, De Buck J (2018) Quantifying fecal shedding of Mycobacterium avium ssp. paratuberculosis from calves after experimental infection and exposure. J Dairy Sci 101:1478-1487

Derakhshani H, De Buck J, Mortier R, Barkema HW, Krause DO, Khafipour E (2016) The features of fecal and ieal mucosaassociated microbiota in dairy calves during early infection with Mycobacterium avium subspecies paratuberculosis. Front Microbiol 7:426

Donnellan S, Stone V, Johnston H, Giardiello M, Owen A, Rannard S, Aljayyoussi G, Swift B, Tran L, Watkins C, Stevenson K (2017) Intracellular delivery of nano-formulated antituberculosis drugs enhances bactericidal activity. J Inter Nanomed 2:146-156

Ferwerda G, Kullberg BJ, de Jong DJ, Girardin SE, Langenberg DM, van Crevel R, Ottenhoff TH, Van der Meer JW, Netea MG (2007) Mycobacterium paratuberculosis is recognized by Toll-like receptors and NOD2. J Leukoc Biol 82:1011-1018

Fournier B (2013) The function of TLR2 during staphylococcal diseases. Front Cell Infect Microbiol 2:167

Gomes MS, Sousa Fernandes S, Cordeiro JV, Silva Gomes S, Vieira A, Appelberg R (2008) Engagement of Toll-like receptor 2 in mouse macrophages infected with Mycobacterium avium induces nonoxidative and TNF-independent anti-mycobacterial activity. Eur J Immunol 38:2180-2189

Hasan Z, Schlax C, Kuhn L, Lefkovits I, Young D, Thole J, Pieters J (1997) Isolation and characterization of the mycobacterial phagosome: segregation from the endosomal/lysosomal pathway. Mol Microbiol 24:545-553

Hines ME, Stabel JR, Sweeney RW, Griffin F, Talaat AM, Bakker D, Benedictus G, Davis WC, de Lisle GW, Gardner IA, Juste RA, Kapur V, Koets A, McNair J, Pruitt G, Whitlock RH (2007) Experimental challenge models for Johne's disease: a review and proposed international guidelines. Vet Microbiol 122:197-222

Holani R, Marin M, Kastelic J, Cobo ER (2018) Host defense peptides as innate immunomodulators in the pathogenesis of colitis. In: Elsevier (ed) Antimicrobial peptides in gastrointestinal disease. Academic Press: Cambridge, MA, USA, pp 133-164

Hostetter J, Steadham E, Haynes J, Bailey T, Cheville N (2003) Phagosomal maturation and intracellular survival of Mycobacterium avium subspecies paratuberculosis in $\mathrm{J} 774$ cells. Comp Immunol Microbiol Infect Dis 26:269-283

Huntley JF, Stabel JR, Paustian ML, Reinhardt TA, Bannantine JP (2005) Expression library immunization confers pro-tection against Mycobacterium avium subsp. paratuberculosis infection. Infect Immun 73:6877-6884

Janeway CA Jr, Medzhitov R (2002) Innate immune recognition. Annu Rev Immunol 20:197-216

Koets AP, Eda S, Sreevatsan S (2015) The within host dynamics of Mycobacterium avium ssp. paratuberculosis infection in cattle: where time and place matter. Vet Res 46:61

Kuehnel MP, Goethe R, Habermann A, Mueller E, Rohde M, Griffiths G et al (2001) Characterization of the intracellular survival of Mycobacterium avium ssp. paratuberculosis: phagosomal $\mathrm{pH}$ and fusogenicity in $\mathrm{J} 774$ macrophages compared with other mycobacteria. Cell Microbiol 3:551-566 
Lamont EA, O'Grady SM, Davis WC, Eckstein T, Sreevatsan S (2012) Infection with Mycobacterium avium subsp. paratuberculosis results in rapid interleukin-1beta release and macrophage transepithelial migration. Infect Immun 80:3225-3235

Lamont EA, Xu WW, Sreevatsan S (2013) Host-Mycobacterium avium subsp. paratuberculosis interactome reveals a novel iron assimilation mechanism linked to nitric oxide stress during early infection. BMC Genomics 14:694

Lamont EA, Talaat AM, Coussens PM, Bannantine JP, Grohn YT, Katani R, Li LL, Kapur V, Sreevatsan S (2014) Screening of Mycobacterium avium subsp. paratuberculosis mutants for attenuation in a bovine monocyte-derived macrophage model. Front Cell Infect Microbiol 4:87

Lee SJ, Noh KT, Kang TH, Han HD, Shin SJ, Soh BY, Park JH, Shin YK, Kim HW, Yun CH, Park WS, Jung ID, Park YM (2014) The Mycobacterium avium subsp. paratuberculosis protein MAP1305 modulates dendritic cell-mediated T cell proliferation through Tolllike receptor-4. BMB Rep 47:115-120

Liu PT, Stenger S, Li H, Wenzel L, Tan BH, Krutzik SR, Ochoa MT, Schauber J, Wu K, Meinken C, Kamen DL, Wagner M, Bals R, Steinmeyer A, Zugel U, Gallo RL, Eisenberg D, Hewison M, Hollis BW, Adams JS, Bloom BR, Modlin RL (2006) Toll-like receptor triggering of a vitamin D-mediated human antimicrobial response. Science 311:1770-1773

Marin M, Holani R, Shah CB, Odeon A, Cobo ER (2017) Cathelicidin modulates synthesis of toll-like receptors (TLRs) 4 and 9 in colonic epithelium. Mol Immunol 91:249-258

Mookherjee N, Brown KL, Bowdish DM, Doria S, Falsafi R, Hokamp K, Roche FM, Mu R, Doho GH, Pistolic J, Powers JP, Bryan J, Brinkman FS, Hancock RE (2006) Modulation of the TLRmediated inflammatory response by the endogenous human host defense peptide LL-37. J Immunol 176:2455-2464

Mortier RA, Barkema HW, De Buck J (2015) Susceptibility to and diagnosis of Mycobacterium avium subspecies paratuberculosis infection in dairy calves: a review. Prev Vet Med 121:189-198

Mucha R, Bhide MR, Chakurkar EB, Novak M, Mikula I Sr (2009) Tolllike receptors TLR1, TLR2 and TLR4 gene mutations and natural resistance to Mycobacterium avium subsp. paratuberculosis infection in cattle. Vet Immunol Immunopathol 128:381-388

Parker AE, Bermudez LE (1997) Expression of the green fluorescent protein (GFP) in Mycobacterium avium as a tool to study the interaction between mycobacteria and host cells. Microb Pathog 22:193198

Periasamy S, Tripathi BN, Singh N (2009) Mechanisms of Mycobacterium avium subsp. paratuberculosis induced apoptosis and necrosis in bovine macrophages. Vet Microbiol 165:392-401

Quesniaux V, Fremond C, Jacobs M, Parida S, Nicolle D, Yeremeev V, Bihl F, Erard F, Botha T, Drennan M, Soler MN, Le Bert M, Schnyder B, Ryffel B (2004) Toll-like receptor pathways in the immune responses to mycobacteria. Microbes Infect 6:946-959

Ralph P, Prichard J, Cohn M (1975) Reticulum cell sarcoma: an effector cell in antibody-dependent cell-mediated immunity. J Immunol 114: 898-905

Rode AKO, Kongsbak M, Hansen MM, Lopez DV, Levring TB, Woetmann A, Odum N, Bonefeld CM, Geisler C (2017) Vitamin D counteracts Mycobacterium tuberculosis-induced cathelicidin downregulation in dendritic cells and allows Th1 differentiation and IFNgamma secretion. Front Immunol 8:656

Rosseels V, Roupie V, Zinniel D, Barletta RG, Huygen K (2006) Development of luminescent Mycobacterium avium subsp. paratuberculosis for rapid screening of vaccine candidates in mice. Infect Immun 74:3684-3686

Rueden CT, Schindelin J, Hiner MC, DeZonia BE, Walter AE, Arena ET, Eliceiri KW (2017) ImageJ2: ImageJ for the next generation of scientific image data. BMC Bioinformatics 18:529
Santos JC, Silva-Gomes S, Silva JP, Gama M, Rosa G, Gallo RL, Appelberg R (2014) Endogenous cathelicidin production limits inflammation and protective immunity to Mycobacterium avium in mice. Immun Inflammation Dis 2:1-12

Schaller-Bals S, Schulze A, Bals R (2002) Increased levels of antimicrobial peptides in tracheal aspirates of newborn infants during infection. Am J Respir Crit Care Med 165:992-995

Schneider CA, Rasband WS, Eliceiri KW (2012) NIH image to ImageJ: 25 years of image analysis. Nat Methods 9:671-675

Shin SJ, Wu C, Steinberg H, Talaat AM (2006) Identification of novel virulence determinants in Mycobacterium paratuberculosis by screening a library of insertional mutants. Infect Immun 74:3825-3833

Slana I, Kralik P, Kralova A, Pavlik I (2008) On-farm spread of Mycobacterium avium ssp. paratuberculosis in raw milk studied by IS 900 and F57 competitive real time quantitative PCR and culture examination. Int J Food Microbiol 128:250-257

Sohal JS, Singh SV, Tyagi P, Subhodh S, Singh PK, Singh AV, Narayanasamy K, Sheoran N, Singh Sandhu K (2008) Immunology of mycobacterial infections: with special reference to Mycobacterium avium subspecies paratuberculosis. Immunobiology 213:585-598

Sonawane A, Santos JC, Mishra BB, Jena P, Progida C, Sorensen OE, Gallo R, Appelberg R, Griffiths G (2011) Cathelicidin is involved in the intracellular killing of mycobacteria in macrophages. Cell Microbiol 13:1601-1617

Sturgill-Koszycki S, Schlesinger PH, Chakraborty P, Haddix PL, Collins HL, Fok AK, Allen RD, Gluck SL, Heuser J, Russell DG (1994) Lack of acidification in Mycobacterium phagosomes produced by exclusion of the vesicular proton-ATPase. Science 263:678-681

Tanaka S, Sato M, Taniguchi T, Yokomizo Y (1994) Histopathological and morphometrical comparison of granulomatous lesions in $\mathrm{BALB} / \mathrm{c}$ and $\mathrm{C} 3 \mathrm{H} / \mathrm{HeJ}$ mice inoculated with Mycobacterium paratuberculosis. J Comp Pathol 110:381-388

Via LE, Fratti RA, McFalone M, Pagan-Ramos E, Deretic D, Deretic V (1998) Effects of cytokines on mycobacterial phagosome maturation. J Cell Sci 111(Pt 7):897-905

Wang JJ, Chen C, Xie PF, Pan Y, Tan YH, Tang LJ (2014) Proteomic analysis and immune properties of exosomes released by macrophages infected with Mycobacterium avium. Microbes Infect 16: 283-291

Weiss DJ, Evanson OA, de Souza C, Abrahamsen MS (2005) A critical role of interleukin-10 in the response of bovine macrophages to infection by Mycobacterium avium subsp paratuberculosis. Am J Vet Res 66:721-726

Weiss DJ, Souza CD, Evanson OA, Sanders M, Rutherford M (2008) Bovine monocyte TLR2 receptors differentially regulate the intracellular fate of Mycobacterium avium subsp. paratuberculosis and Mycobacterium avium subsp. avium. J Leukoc Biol 83:48-55

Yang CS, Shin DM, Kim KH, Lee ZW, Lee CH, Park SG, Bae YS, Jo EK (2009) NADPH oxidase 2 interaction with TLR2 is required for efficient innate immune responses to mycobacteria via cathelicidin expression. J Immunol 182:3696-3705

Young-Speirs M, Drouin D, Cavalcante PA, Barkema HW, Cobo ER (2018) Host defense cathelicidins in cattle: types, production, bioactive functions and potential therapeutic and diagnostic applications. Int J Antimicrob Agents

Zanetti M (2005) The role of cathelicidins in the innate host defenses of mammals. Curr Issues Mol Biol 7:179-196

Zur Lage S, Goethe R, Darji A, Valentin-Weigand P, Weiss S (2003) Activation of macrophages and interference with CD4+ T-cell stimulation by Mycobacterium avium subspecies paratuberculosis and Mycobacterium avium subspecies avium. Immunology 108:62-69

Publisher's note Springer Nature remains neutral with regard to jurisdictional claims in published maps and institutional affiliations. 